\title{
Climate Change and Vibrio cholerae in Herring Eggs: The Role of Indigenous Communities in Public Health Outbreak Responses
}

\author{
Paivi Abernethy, Shannon Waters, Tim Kulchyski, Dave Rolston, Helena Swinkels, Gethsemane \\ Luttrell, Linda Pillsworth
}

A R T I C L E IN F O

Keywords:

Climate change

Environmental health

Outbreak intervention

Community partnerships

Local knowledge

Cultural safety

https://doi.org/10.32799/ijih.v16i2.33236

\author{
A B S T R A C T
}

A UTHOR I N F O

\begin{abstract}
Climate change brings about novel types of public health emergencies. Unforeseen challenges put additional pressure on health systems and require innovative approaches to address emerging needs. The health of Indigenous Peoples is particularly impacted by the changing climate, because of their close connection to the land. For instance, the physical, emotional, mental, and spiritual well-being of coastal First Nations in British Columbia (BC), Canada, is interconnected with the abundance of healthy marine food sources that form the base of local traditional diets. The 2018 discovery of Vibrio cholerae illness in those who had eaten contaminated herring eggs not only had a clinical health impact but also created concerns for the safety of local food systems. The limited magnitude of the outbreak demonstrates the critical importance of collaborative partnerships between coastal First Nations communities in BC and health authorities working together in outbreak investigations. Yet, the lack of procedures that address cultural and institutional differences led to unnecessary discrepancies in the approach. This paper introduces the public health intervention used during the first ever Vibrio cholerae outbreak in coastal BC. The intervention has the potential to inform best practices when developing emergency response protocols potentially affecting Indigenous people and traditional foods. In this qualitative case study of the formal institutional documents and narratives of the key partners involved in the response, we assess the intervention, highlight the challenges and enablers, share lessons learned, and identify knowledge requirements to improve confidence in the traditional food system and support early warning systems.
\end{abstract}

Paivi Abernethy, PhD, MRes, MSc, Climate Change and Health Specialist, Environmental Public Health Services, First Nations Health Authority, Vancouver, British Columbia, Canada; Research Fellow, Centre for Global Studies, University of Victoria, Victoria, British Columbia, Canada; Adjunct Professor, School of Environment, Resources and Sustainability, University of Waterloo, Waterloo, Ontario, Canada. Email: pabernethy@uvic.ca

Shannon Waters of Stz'uminus First Nation, MD, MHSc, Medical Health Officer, Vancouver Island Health Authority (Island Health), Duncan, British Columbia, Canada; Clinical Assistant Professor, School of Population and Public Health, University of British Columbia, Vancouver, British Columbia, Canada; Cowichan Watershed Board, Duncan, British Columbia, Canada 
Tim Kulchyski of Cowichan Tribes, BSc, Fisheries Biologist/Natural Resource Consultant, Cowichan Tribes, Duncan, British Columbia, Canada; Cowichan Watershed Board

Dave Rolston, BSc, DipNautSci, DipFishWild, Fisheries Manager, Tseshaht First Nation, Port Alberni, British Columbia, Canada

Helena Swinkels, MD, MHSc, FCFP, FRCPC, Medical Officer, First Nations Health Authority; Clinical Assistant Professor, School of Population and Public Health, University of British Columbia

Gethsemane Luttrell, BSc, BTech, CPHI(C), Environmental Public Health Services, First Nations Health Authority

Linda Pillsworth, BTech, CPHI(C), Manager, Environmental Public Health Services, First Nations Health Authority

\section{Abbreviations}

$\begin{array}{ll}\text { BC } & \text { British Columbia } \\ \text { BCCDC } & \text { British Columbia Centre for Disease Control } \\ \text { CFIA } & \text { Canadian Food Inspection Agency (Government of Canada) } \\ \text { DFO } & \text { Department of Fisheries and Oceans (Government of Canada) } \\ \text { ECCC } & \text { Environment and Climate Change Canada (Government of Canada) } \\ \text { FNHA } & \text { First Nations Health Authority (jurisdiction across British Columbia) }\end{array}$

Acknowledgements

Thank you to Alexa Norton and our anonymous reviewers for very useful feedback.

\section{Introduction}

Climate change is affecting the health of Indigenous communities in unforeseen ways, requiring innovative approaches to health protection if health authorities want to meaningfully and effectively protect public health (Lynn et al., 2013). In Alaska, tribal health organizations and communities have been at the forefront of identifying climate change impacts (Brubaker et al., 2011) and developing community-based solutions to address climate change and related health challenges (e.g., U.S. Climate Resilience Toolkit, 2020). Furthermore, while Indigenous cultural safety has been widely discussed in primary health care (Browne et al., 2015) and health promotion in public health (Baba, 2013), it has received less attention in health protection in emergency contexts, often reducing the effectiveness of interventions and potentially creating additional harm (Fogarty et al., 2018; Spence, 2017). This paper is particularly aiming to reach non-Indigenous stakeholders involved in environmental health related disease outbreaks that involve Indigenous communities. We use the first ever Vibrio cholerae (V. cholerae) outbreak in coastal British Columbia (BC), Canada, in 2018 caused by contaminated herring eggs, to illustrate the value of proactive community engagement in improving the effectiveness of emergency responses when dealing with Indigenous health impacts of climate change.

In coastal BC, warmer ocean temperatures have caused an increase in harmful algal blooms and brought infectious diseases new to the area (Marinucci et al., 2014; Moore et al., 2008; Turner \& Clifton, 2009). Infectious disease or toxin outbreaks associated with seafood and 
fish are of particular concern for coastal First Nations, because many species, such as Pacific herring (Clupea pallasii), are culturally important to many communities (Moss, 2016). Seafood and fish not only hold significant cultural value in coastal First Nations' diets but have nutritional, economic, and sociocultural importance. According to Donatuto et al. (2011), "seafood represents a symbolic, deeply meaningful food source that is linked to a multidimensional [community-specific] concept of health" (p. 103). Sometimes the spiritual value of specific foods may even exceed the risk of becoming ill for community members. Often, typical interventions recommended by public health authorities, such as cooking, do not take traditional practices into consideration. This may reduce effectiveness of the overall response.

In Canada, the division of powers across federal and provincial jurisdictions is defined in the Constitution Act (1867, s. 91[24]), stipulating that "Indians, and Lands reserved for the Indians" are a matter of federal jurisdiction. This has caused significant issues with health jurisdiction and program delivery as it pertains to First Nations people, to whom this statement refers. The provinces are responsible for providing and administering the majority of health care in Canada, including communicable disease control and food safety legislated under provincial public health acts. Federal health care is provided to First Nations through inherited fiduciary duties to First Nations. This division has caused a distinction between general health care and health care of First Nations. Until recently, there has been a reluctance of provincially administered health services to include First Nations fully in the health system (First Nations Health Council, 2011).

The Health Transfer Policy (National Health and Welfare \& Treasury Board of Canada, 1989) aimed to address this patchwork of responsibilities and recognize the importance of the role of First Nations in meeting the needs of their communities. It enabled First Nations control over community services. Communities are assuming responsibility over their community health programs at their own pace, either at the individual community or aggregate level. The benefits of the policy include "increased community awareness of health issues, more culturally sensitive health care delivery, improved employment opportunities for community members, a sense of empowerment and self-determination, and an improvement in the community's health status" (Lavoie et al., 2011, p. 3).

In $\mathrm{BC}$, a series of leadership and transformative change accords, a First Nations health plan, health governance and framework agreements, and health administrative arrangements led to a tripartite agreement to establish the first province-wide First Nations Health Authority (FNHA) in 2013 (BC Tripartite Framework Agreement, 2011; First Nations Health Council, 2011; O'Neil et al., 2016). The FNHA addresses service gaps through new partnerships, closer collaboration, health systems innovation, and reform and redesign of health programs and services to ensure that BC First Nations receive equitable services and care. The unique characteristic of the BC First Nations Health Governance Structure is that it is run by First Nations, for First Nations, which enables FNHA to operate as a health and wellness partner to all BC First Nations. Furthermore, the new Health Governance Structure supports First Nations communities' own health decision-making and self-determination. 
The extension of jurisdictional authority for communicable disease control varies by province. In some cases, provinces defer to federal health programs for some or all public health services; in others, delegated authorities are extended. In BC, the control of communicable disease is within the jurisdictional mandate of regional health authorities and their respective medical health officers (Public Health Act, 2008, c. 28) to prevent, investigate, and respond to human illness outbreaks. The BC Centre for Disease Control (BCCDC) provides provincial disease surveillance functions. The FNHA's Environmental Public Health Services provides advisory services for food safety and prevention of communicable diseases under the $\mathrm{BC}$ Tripartite Framework Agreement (2011), and is not delegated authorities under the Public Health Act for management and control of outbreaks. The BC Foodborne Illness Outbreak Response Protocol (2012) was developed to support clarity in roles, responsibilities, and processes where foodborne illness outbreaks occur across shared jurisdiction. The protocol aimed to enhance public health and safety by maximizing efficiency and effectiveness through enhanced communication and collaboration among the agencies.

The first outbreak of $V$. cholerae on the coast of BC in March 2018 was associated with consumption of herring eggs and involved a multi-agency emergency response following public health standards for infectious diseases. V. cholerae is best known for causing epidemic cholera, an acute diarrheal infection with sometimes fatal consequences resulting from ingestion of food or water contaminated with the bacteria. However, only two serotypes of V. cholerae, $\mathrm{O} 1$ and O139, produce the potent enterotoxin (cholera toxin) responsible for the lethal symptoms of the disease (Mandal et al., 2011). There are more than 150 other serotypes of $V$. cholerae that cause varying degrees of illness in humans (Karunasagar, 2009). The serotype of the strain involved in the outbreak in BC was found to be non-O1/O139, without the risk of epidemic cholera. The most common symptom following the intake of food or water contaminated by non-O1/O139 $V$. cholerae is mild to severe watery diarrhea (Baker-Austin et al., 2017). Non-O1/O139 $V$. cholerae can also cause other problems, such as bacteremia and wound infections (Engel et al., 2016). Bacteremia caused by non-O1/O139 V. cholerae can manifest in many different ways, ranging from lethargy, fever, chills, and decreased blood pressure to meningitis, eye inflammation, cough, and shortness of breath (Engel et al., 2016). Severe health outcomes can include neurological impairment, lower limb amputation, and death.

$V$. cholerae colonies are common to coastal waters but their abundance often surges with events associated with climate change, such as rising water temperatures and lower salinity caused by excessive rainfall (Hunter \& Wade, 2015; Vezzulli et al., 2013). An increasing number of human infections have been diagnosed in connection with heat waves in northern Europe (Baker-Austin et al., 2017) but had not been recorded in coastal BC until this outbreak. In this paper, we discuss a public health emergency intervention that offers useful lessons for future emergencies involving Indigenous communities and supports a paradigm shift toward more holistic emergency management planning. 


\section{Methods}

This qualitative study used a transdisciplinary retroactive developmental evaluation approach. We drew from stakeholder knowledge and literature in diverse disciplines to adequately investigate the complexity associated with a specific public health emergency case study involving two First Nations communities in coastal BC. We adapted Patton's (2011) approach to constructively assess an intervention modified and implemented in the midst of a crisis requiring urgent action, whereby activities were uncertain and consequences contentious. Developmental evaluation integrates an active learning experience and social-change-enhancing mechanisms in the evaluation process. It is often used in Indigenous health intervention research (Laycock et al., 2019; Shrivastava et al., 2019).

Our research method combined a literature review, interviews, and auto-ethnographic storytelling (Patton, 2002). Analyzed data included written and oral narratives that emerged from the personal experiences of participating professional stakeholders within their respective personal and institutional cultures (both Indigenous and non-Indigenous). A qualitative analysis of formal institutional documents and narratives of the key partners (co-authors) who were involved in the response was conducted. The co-authors include representatives from the two affected First Nations communities. The data analysis was guided by Patton's (2011) retroactive developmental evaluation questions, such as: What were the critical incidents and contextspecific aspects that shaped the intervention? and Who was involved in the collaborative efforts to address the situation and how did they influence the outcomes? The data were analyzed manually, without data analysis software. Identified categories were developed based on the themes that emerged from the findings (Patton, 2002). The findings were verified by data triangulation combined with consensus among the co-authors.

\section{Relationship}

Environmental public health programming for First Nations communities in BC includes health protection activities in food safety and communicable disease control. FNHA environmental health officers have established foundational relationships with their respective First Nations community health and resource management teams through their long-standing service in communities. In any issue affecting communities, these relationships are integral to effective assessment, and to identifying and implementing intervention strategies. In this case study, existing community relationships between FNHA staff and key community roles in Cowichan Tribes and Tseshaht Nation, the affected communities, together with the awareness of their capacity for involvement, enabled the communities to be actively engaged with the outbreak investigation team during planning and decision-making.

\section{Limitations}

This is a qualitative case study, which by the nature of the approach may introduce some personal bias. Impacts of bias were reduced by inviting representatives from the main partner 
organizations as co-authors and appointing a lead author who was not involved in the outbreak response. However, the lead author is an employee of FNHA and specializes in climate change impacts on health.

\section{Intervention}

The outbreak had various complexities: Confirmed cases included First Nations patients, the pathogen was new to the area, and the response required the involvement of multiple authorities and agencies.

\section{Key Partners}

The key partners involved were regional, provincial, and First Nations health agencies, directly affected First Nations communities, and relevant federal ministries (see Table 1). Provincial communicable disease management was provided by the regional health authority (Island Health) and BCCDC. Ocean-related activities in Canada are regulated by the federal Department of Fisheries and Oceans (DFO), leading to the involvement of various federal ministries. Finally, the operational directives of the FNHA require community- or Nation-based approaches to health and recognize Indigenous local authority and self-determination. These strongly guided the intervention.

\section{Table 1}

Key Partners and Their Roles

\begin{tabular}{|l|l|}
\hline Stakeholder & Role \\
\hline BC First Nations Partners \\
\hline $\begin{array}{l}\text { Directly affected First } \\
\text { Nations communities: } \\
\text { Cowichan Tribes and } \\
\text { Tseshaht Nation }\end{array}$ & $\begin{array}{l}\text { Key partners advising and guiding the investigation team; vessel } \\
\text { support for environmental sampling; participation in public } \\
\text { health risk communication in collaboration with FNHA and } \\
\text { Island Health }\end{array}$ \\
\hline $\begin{array}{l}\text { First Nations Health } \\
\text { Authority (FNHA) }\end{array}$ & $\begin{array}{l}\text { Environmental public health services; investigation of handling } \\
\text { and preparation of harvested product; environmental sampling } \\
\text { (food and marine water); risk assessment, decision-making, and } \\
\text { public health risk communication in collaboration with Island } \\
\text { Health and affected communities }\end{array}$ \\
\hline $\begin{array}{l}\text { Regional Partners } \\
\text { Island Health (regional } \\
\text { health authority) }\end{array}$ & $\begin{array}{l}\text { Outbreak lead and jurisdictional authority (Public Health Act); } \\
\text { direction on management and control of the outbreaks, } \\
\text { including coordination, case follow-up, and risk communication }\end{array}$ \\
\hline Provincial Partners & $\begin{array}{l}\text { Laboratory analyses (diagnostic and environmental); research } \\
\text { support }\end{array}$ \\
\hline $\begin{array}{l}\text { BC Centre for Disease } \\
\text { Control (BCCDC) }\end{array}$
\end{tabular}




\section{Table 1 con't}

\begin{tabular}{|l|l|}
\hline Stakeholder & Role \\
\hline \multicolumn{2}{|l|}{ Federal Partners } \\
\hline $\begin{array}{l}\text { Public Health Agency of } \\
\text { Canada, National } \\
\text { Microbiology Laboratory }\end{array}$ & Laboratory analyses (serotype and genome sequencing) \\
\hline $\begin{array}{l}\text { Environment and Climate } \\
\text { Change Canada (ECCC) }\end{array}$ & Information sharing (routine marine water sampling) \\
\hline Health Canada & Advisory opinion \\
\hline $\begin{array}{l}\text { Department of Fisheries } \\
\text { and Oceans (DFO) }\end{array}$ & $\begin{array}{l}\text { Jurisdictional authority to issue fisheries closure; vessel support } \\
\text { for environmental sampling }\end{array}$ \\
\hline
\end{tabular}

$\mathrm{BC}$ regional health authorities and federal environmental health programs have progressively aimed to increase communication and collaboration related to communicable diseases affecting First Nations communities. These efforts include establishing protocols to clarify roles and responsibilities, communication, and coordination. Because the arrangements are relatively new - the collaborative public health emergency protocols are still being tested in practice - the emerging unpredictability of climate change and new pathogens generate additional pressure on the system, as was the case with this V. cholerae outbreak.

Prior to the outbreak, a draft Communicable Disease Protocol had been established between the regional health authorities and the FNHA to improve clarity of roles and responsibilities and to support effective communication and collaboration in the event of a communicable disease outbreak. While this protocol provided some guidance, it did not address roles of other agencies. For instance, the federal Public Health Agency of Canada's National Microbiology Laboratory is typically not involved; however, it was critical as it specializes in identifying diseases or strains beyond the capacity of provincial labs. Environment and Climate Change Canada (ECCC) monitors water quality (temperature, salinity, total coliforms, and E. coli) in shellfish harvest areas, providing useful information about marine conditions at the time of an outbreak. DFO, in turn, is responsible for fisheries openings and closurescommercial, recreational, Indigenous, and food fisheries are subject to closures for conservation, safety, contamination, seasonal, or other reasons.

\section{Events as They Unfolded}

In March 2018, three individuals, all in First Nations communities, were confirmed by laboratory testing to have $V$. cholerae infections. Their illnesses were associated with consuming herring eggs harvested in two coastal areas on Vancouver Island, BC. While three cases were lab confirmed, it was later discovered that other cases were known throughout the First Nations communities. Some affected individuals sought health care before the outbreak was known; some were identified but not followed up with; and others were rumoured to have been infected but were never identified. The same strain of $V$. cholerae isolated from patients was also found in herring egg and marine water samples collected from the two areas. Because herring eggs are 
important traditional seafood for many First Nations in BC, providing sociocultural, nutritional, and economic benefits, special attempt was made to practise cultural sensitivity with affected communities.

This $V$. cholerae outbreak intervention commenced as a result of regular case follow-up. Island Health notified the FNHA of a possible cluster of illnesses where the common food source appeared to be herring eggs. The FNHA's Environmental Public Health Services team for the Vancouver Island region communicated this to the health and fisheries leads in the affected First Nations communities. The team worked closely with community partners to investigate the source of the herring eggs, collection sites and methods, handling practices, and distribution within and outside respective communities. Island Health and DFO collaboratively issued a local fisheries closure as a precautionary measure. There were a number of uncertainties in the early stages of the outbreak: the $V$. cholerae serotype, source, and extent of the infection; the potential wider distribution of herring eggs within and outside of the community; and lack of sufficient information about the extent of the outbreak. Public health agencies (FNHA, Island Health, and BCCDC) held internal briefings and requested an advisory opinion from Health Canada. The requested advisory opinion included recommendations for food handling (see Appendix), considerations for future assessment, and decisions that needed to be considered. Health Canada also highlighted that while the risk was low to the general population, it was potentially higher in coastal First Nations due to traditional herring egg consumption. Furthermore, the requested advisory opinion emphasized that there are currently no environmental parameters to predict the levels of $V$. cholerae effectively.

The initial public health messaging was based on a possible O1/O139 cholera outbreak and generalizations because the serotype of the bacteria was not known. To reduce the risk of illness in communities located in the vicinity of the contaminated harvest sites and communities more distant but known to actively utilize the area for traditional harvesting, the FNHA distributed the health advice broadly. The delay in health authorities' ability to verify that the outbreak did not involve the more dangerous O1/O139 cholera strains unnecessarily heightened fear in the general public. While the timely diagnostic support by the National Microbiology Laboratory was a great strength, it also brought attention to the lack of preparedness for emerging pathogens. The FNHA, Island Health, and BCCDC determined that in the absence of information specific to the identified form of $V$. cholerae and contributing factors, the advisory regarding a potential risk for O1/O139 cholera strains should remain in place until further advice was received from Health Canada. Education about safe food handling practices was provided to communities, specifically targeting members known to consume herring eggs. The FNHA team provided outbreak guidance to the health nurse and fisheries staff of the directly affected First Nations, who were instrumental in supporting the public outreach.

While the outbreak was limited to three confirmed cases and was addressed successfully in terms of health outcomes, the experience generated a desire among the involved partners to improve the formal protocols for public health outbreaks. Needed improvements relate to technical information for better decision-making, modes of operation (e.g., practical aspects of 
coordination, further improved cultural safety, etc.), and more effective collaboration, including better ways of engaging communities and communications outreach.

\section{Discussion}

With the unpredictability and increasing frequency of incidents associated with climate change, new approaches are needed for best practices in public health and emergency management. This $V$. cholerae outbreak intervention illustrates a promising practice and a paradigm shift. Identifying success factors and lessons learned will assist in developing new approaches, particularly when working with Indigenous communities.

\section{Drivers and Enablers That Made the Outbreak Response Successful}

Three main drivers identified for the success of the intervention include (a) existing working relationships between key stakeholders, (b) community engagement and mutual guidance, and (c) openness and timeliness of communication with First Nations communities.

The existing relationships between the FNHA, Island Health, BCCDC, and various government departments enhanced effective collaboration between the partnering agencies. One of the common challenges for collaboration between government agencies and First Nations is the understandable mistrust of externally imposed processes, due to continuing colonialism and injustices First Nations people experience in the contemporary health care system (Anderson \& Smylie, 2009). The trust relationship with FNHA staff enabled open information sharing between community partners in the affected First Nations and the environmental health investigation team from the FNHA and Island Health.

The directly affected First Nations communities were actively engaged in both knowledge sharing and the outbreak investigation as partners with the health authorities. They guided the context-specific troubleshooting by, for instance, describing their food harvesting and preparation practices. This information was integral to the assessment of risk because communities have varying practices of harvesting and preparing herring eggs. Differences in practices can create different contributing factors to an outbreak, which complicate both investigation and control; for instance, some preparation practices, such as consuming herring eggs raw, increase the likelihood of an infection. Working closely with the affected communities improved understanding of community practices, situational assessment, and meaningfulness of recommendations to both public health agencies and communities.

Top-down public health approaches led by professionals are based on the current legislative mandate, and Indigenous communities are usually not directly involved in response and decision-making related to public health emergencies. The transparent communication and direct engagement used by the First Nations partners helped bring community concerns to the forefront. This, in turn, made it easier for communities to accept and follow recommendations because they saw their concerns and knowledge reflected in the guidance. Limited community staff capacity was occasionally a challenge during the outbreak, but efforts to coordinate input and guidance were established to overcome the limitations. Our findings are well aligned with the health promotion literature (Butterfoss et al., 2006; Minkler \& Wallerstein, 2012) that builds 
on Putnam's (1994, 2000) findings about the importance of trust, social networks, and sense of equity in information flows and reciprocal action.

\section{Having the Right Knowledge to Make Good Decisions}

Both Western and Indigenous science as well as local knowledge are needed to make good decisions during a public health emergency. Indigenous knowledges and traditional practices are diverse and community-specific, connected to the local language and landscape (Greenwood et al., 2017). While the knowledge about harvesting and food handling information coming from both Western and Indigenous science was highlighted above, our reflective analysis identified some critical gaps. We focus particularly on the specific needs of BC coastal First Nations.

One of the issues relates to challenges with and lack of sufficient monitoring - both environmental monitoring of the quality of water and monitoring of the harvest. The length of the $\mathrm{BC}$ coastline precludes monitoring at all potential spawning areas prior to harvest. Harvest areas also change from year to year, which is further complicated by climate change. Spawning of herring takes place where kelp grows (Haegele \& Schweigert, 1985; Keeling et al., 2017; Thornton et al., 2010). As kelp is growing further north due to changing temperatures and other factors, spawning is also moving northward. Historical data for sea surface temperatures have helped monitor shellfish food safety, but climate change makes risk predictions more challenging. While ECCC is increasing the geographic range of its temperature monitoring, data are currently not publicly available. Monitoring is also resource intensive. Since the ocean temperatures close to the shore can vary between different location-specific microclimates, this lack of basic monitoring data highlights the challenges both authorities and local fishermen are facing when assessing health of the harvest. The lack of resources and a need for climate-changespecific monitoring has been highlighted in the climate change literature (BCCDC, 2016; Hopkins et al., 2016; Stephen \& Duncan, 2017). Yet the emergent incidences of, for instance, $V$. cholerae infections, tend to be viewed as a trend related to the changing climate.

In this particular case, the connection to higher temperatures was not that clear. While the ocean temperatures in the northeastern Pacific Ocean were abnormally high $\left(1-4{ }^{\circ} \mathrm{C}\right.$ above average) in 2015-2016 (Auth et al., 2018), the recorded temperatures in 2018 during the $V$. cholerae outbreak were within normal range. The quantity of rainfall was also within normal range. Rainfall did cause significant turbidity and delayed the harvest; this, together with raking practices, created disturbance and resuspension, and may have contributed to the problem. Sparse monitoring in the area did complicate the assessment. Water temperatures in the implicated harvesting sites are not regularly monitored and the data used in the assessment were projections from the closest monitoring station in another area.

Similarly, there are no data presently available that could help determine the presence of $V$. cholerae. We know that salinity, brackish water, and rainfall are all potential factors (BakerAustin et al., 2017; Vezzulli et al., 2013), but the lack of understanding of the conditions related to risks was identified as a critical gap in the process. These limitations, alongside the restraints of local laboratory capacity for serotyping and general analysis in First Nations, and to some 
extent even regionally or provincially, prevent identifying contaminated product before it is in the hands of community members. First Nations harvesting does not fit into the testing used in large-scale commercial fishing, highlighting the need to look at harvesting through an Indigenous lens.

The involved health agencies and affected First Nations collaboratively established action items to find solutions to these issues, such as gathering environmental data that would help determine why herring spawning is moving northward and predictive factors for the presence of $V$. cholerae. During this outbreak, the diagnostic procedures were limited by the existing monitoring structures. The self-reflection process revealed that more wholistic and proactively engaging approaches, involving communities and scientific experts, are needed to help minimize future outbreaks. While establishing capacity for serotype analyses at a local or regional level is not realistic, community-level monitoring of water temperatures and species regularly consumed by coastal First Nations could potentially be arranged as a collaboration between First Nations partners and government laboratories.

The unforeseen outbreak also revealed challenges beyond climate change. Health practitioners discovered that they did not know local herring egg harvesting practices. Thanks to the partnership with local First Nations communities, their modern community harvesting methods were shared with the health authorities' investigation team. Harvesting and food preparation practices vary between Indigenous communities, which affects the degree of potential health risks caused by specific outbreak situations. For instance, raw herring egg consumption is a tradition only in some communities and falls outside of the scope of the existing monitoring structures, such as the Canadian Shellfish Sanitation Program.

The existence of diverse authorities on fishing rights further complicates the situation. For example, federal monitoring mandates are limited to shellfish, yet constitutional Aboriginal harvesting rights in Canada include participation in either commercial economic fisheries or food, social, and ceremonial fisheries, and are federally protected and regulated. The rights are guaranteed under Section 35 of the Canadian Charter of Rights and Freedoms (Constitution Act, 1982) and were further clarified by a court case with Musqueam Indian Band (R. v. Quipp, 2011). However, First Nations may also have fishing authority through various hereditary law or governance mechanisms that are generally not recognized by DFO. The economic fishery that includes spawn-on-kelp is federally regulated by DFO, while the food, social, and ceremonial fishery is a federally protected Indigenous right (Constitution Act, 1982). Furthermore, First Nations fishermen and their administration operate on federal Crown reserves and the water column is also federal Crown jurisdiction, each of which is governed by different ministries. Federal Crown reserves were defined by the Indian Act of 1876 as the restricted locations where First Nations were allowed to live (Hanson, n.d.). However, generally Canadian constitutional Aboriginal harvesting rights extend beyond the reserves and apply within the traditional territory of a given Indigenous community where their ancestors lived and, from the colonial legal perspective, only on Crown land (Truesdale \& Brooks, 2017). Crown land refers to the public lands owned by the federal and provincial governments, as understood by current Canadian law. 
With various regulators at both provincial and federal levels, climate change threats to Indigenous health and food systems are complicated to manage. Canadian national climate change adaptation plans have highlighted the current lack of attention to the specific needs of populations already exposed to extensive social and socioeconomic stressors, such as Indigenous communities (Panic \& Ford, 2013). First Nations tend to primarily harvest outside of the commercial market (Harris \& Millerd, 2010), and coastal Indigenous Peoples (in general) consume 15 times more seafood per person than the non-Indigenous population (CisnerosMontemayor et al., 2016). This statistic reflects the cultural value of seafood in coastal communities and makes their food security more threatened by climate change.

Cumulative impacts of climate change, resource extraction, pollution, and large-scale commercial harvesting are also relevant to this outbreak. Together they have contributed to the drastically reduced quantities of harvest in the Pacific Ocean. For instance, herring populations have declined throughout the northeast Pacific (Thornton et al., 2010; Xu et al., 2019). However, in the areas of the outbreak, the herring stock has remained strong, which unintentionally complicated the contact tracing. According to local First Nations' cultural tradition, there is a moral obligation to share the richness of the catch with communities less fortunate with their harvest (also known as sharing the bounty). Disseminating the public health messaging through these informal food-sharing pathways was a challenge. Communication networks tend to operate well within culturally related communities, and identifying harvest-sharing pathways that reach outside the immediate communities can get significantly more complicated. Broad outreach of communication became critical, as unspecific rumours about the general safety of herring eggs spread to more distant coastal communities because of their significance. The extent of informal information flows and development of rumours highlights the importance of using various types of knowledge and developing broad coordinated public health communication networks within and between Indigenous communities.

Our observations highlight the need for greater interdisciplinary collaboration and proactive community engagement to better minimize climate change threats to public health. While public health literature acknowledges the need for interdisciplinarity (Aron \& Patz, 2001; Rodriguez-Mozaz \& Weinberg, 2010; Tirado et al., 2010), and community-based participatory research is gaining some traction in environmental health (Kwiatkowski, 2011; McClymont Peace \& Myers, 2012; Wine et al., 2017), public health authorities still remain vague about to what degree and when communities should be engaged. Outbreak response is typically seen as a medical investigation and response with confidentiality requirements, and the practical and moral value of community participation is not recognized.

It could also be useful to engage both natural and social scientists from other disciplines in climate health discussions. For instance, environmental governance literature has long been explicit that (a) knowledge needed for effective governance is dispersed and specialized, requiring collaborative approaches to decision-making (Ansell \& Gash, 2008; Berkes, 2010); and (b) for knowledge to be meaningful and useful for all stakeholders, it needs to be co-created and 
perceived as relevant, credible, and legitimate to the stakeholders expected to use the knowledge (Cash et al., 2003; Raymond et al., 2010).

\section{The Importance of Good Relationships and Trust}

Western science and governing structures tend to underestimate the critical role trust plays in social interactions. However, Putnam's $(1994,2000)$ studies on the role of trust in information flow and reciprocity in collective action, and Chino and DeBruyn's (2006) emphasis on the role of trust in Indigenous public health, demonstrate how trust may need take a much more central role in public health interventions.

As regional health authorities in BC are the first point of contact for any communicable disease outbreak, it is essential that a trusting relationship exist with First Nations community members to allow for complete and open information sharing during case follow-up and investigation. The regional health authority in this case, and often in other cases, experienced some challenges in making contact with potentially infected individuals, and in obtaining all pertinent information necessary to identify contamination sources and contributing factors. Interactions between the health system and First Nations communities are still far from optimal because of ongoing colonialism (de Leeuw et al., 2012; Kurtz et al., 2008). The colonial trauma and lack of appropriate cross-cultural understanding, made worse by the often racist nonIndigenous narrative, still create situations that further increase mistrust between partners (Chrismas, 2012; FNHA, 2016; Narine, 2013; Loppie et al., 2014). While the FNHA ended up playing a pivotal role because of its existing relationships with the communities, community nurses indicated that they could have been used more effectively during the outbreak. Community nurses have strong relationships in communities, and the success of case follow-up and communications could be improved by increasing their role, particularly in cases of fear of reporting or shame, lack of trust, and so on.

The unfortunate impact of the outbreak is the fractured community trust in the safety of their traditional food source. Even after lifting the fisheries closure in 2019, communities continued to abstain from self-harvesting due to fear, which forced them to purchase this traditional food from elsewhere. Indeed, coastal communities have requested the FNHA to help develop a monitoring and data system to improve confidence in their traditional food safety. They would like to have local temperature monitoring or sampling before and during harvest, and to build a better understanding of how environmental factors influence the presence of bacteria or toxins.

The idea of an Indigenous food safety monitoring system is not new. Narratives shared during this self-reflective analysis revealed that 10-15 years ago, a system was designed and about to be implemented, in which BC coastal First Nations communities collaborated with the Canadian Food Inspection Agency (CFIA) to collectively monitor the safety of traditionally relevant fish and seafood species. Samples would have been collected by the communities and analyzed by CFIA. Regrettably, the individual leading the project at CFIA retired and the agency chose to close down the project. The story highlights the critical importance of personal relationships, but also the system's vulnerability to the power of individual gatekeepers who 
choose to prioritize differently. This example emphasizes the need for new system-wide collaborative approaches involving a multitude of personal relationships and a governance model that is permanently embedded in administrative structures.

Conventional emergency response protocols in public health tend to be based on calculated risks (including human health risk, which does not incorporate cultural aspects) and top-down command and control models (Donatuto et al., 2011). Lessons learned during this outbreak are summarized in Table 2. The unpredictability of climate change has created a realm of uncertainty, but it is creating opportunities for more inclusive and effective outbreak interventions. The value of a developmental evaluation approach is that it helps develop next steps to improve the process.

\section{Table 2}

Lessons Learned from the V. cholerae Outbreak on the BC Coast, 2018

\begin{tabular}{|c|c|c|}
\hline $\begin{array}{l}\text { Identified } \\
\text { Themes }\end{array}$ & What Went Well & Gaps/Opportunities for Improvement \\
\hline $\begin{array}{l}\text { Effective } \\
\text { partnerships }\end{array}$ & $\begin{array}{l}\text { Collaboration of } \\
\text { stakeholders } \\
\text { - For example, marine } \\
\text { vessel support: } \\
\text { Vessels and skilful } \\
\text { drivers, guidance } \\
\text { regarding routes were } \\
\text { provided by various } \\
\text { stakeholders, } \\
\text { including the affected } \\
\text { First Nations } \\
\text { communities }\end{array}$ & $\begin{array}{l}\text { Some staff in regional health authorities and } \\
\text { other government agencies lack understanding } \\
\text { of First Nations cultures } \\
\text { - Advanced training in cultural interaction } \\
\text { beyond the current basic mandatory } \\
\text { cultural safety training course could be } \\
\text { made mandatory, especially for } \\
\text { communicable disease control staff } \\
\text { Communication between stakeholders could be } \\
\text { improved } \\
\text { - Coordination of information between } \\
\text { Island Health and FNHA } \\
\text { Better coordination of follow-up interviews } \\
\text { between Island Health, FNHA, and the } \\
\text { First Nations communities }\end{array}$ \\
\hline $\begin{array}{l}\text { Power } \\
\text { symmetry and } \\
\text { empowerment }\end{array}$ & $\begin{array}{l}\text { Inclusion of the affected } \\
\text { First Nations communities } \\
\text { in decision-making at } \\
\text { interagency outbreak } \\
\text { meetings }\end{array}$ & $\begin{array}{l}\text { Health authorities and other government } \\
\text { agencies need greater understanding of the } \\
\text { lived realities of First Nations communities, } \\
\text { related to reliance on traditional foods, } \\
\text { harvesting, and food preparation practices } \\
\text { - Proactive engagement of communities in } \\
\text { emergency management and disease } \\
\text { outbreak planning }\end{array}$ \\
\hline
\end{tabular}


Table 2 con't

\begin{tabular}{|c|c|c|}
\hline $\begin{array}{l}\text { Identified } \\
\text { Themes }\end{array}$ & What Went Well & Gaps/Opportunities for Improvement \\
\hline $\begin{array}{l}\text { Changing } \\
\text { patterns of } \\
\text { collaboration }\end{array}$ & $\begin{array}{l}\text { Having the support of the } \\
\text { First Nations in } \\
\text { investigation, sampling, } \\
\text { and risk communication }\end{array}$ & $\begin{array}{l}\text { Inability of environmental agencies to } \\
\text { mobilize for supplemental marine water } \\
\text { quality monitoring; time and resource } \\
\text { restrictions precluded additional marine water } \\
\text { quality information } \\
\text { - Innovative, collaborative Indigenous } \\
\text { community-led monitoring systems may be } \\
\text { a solution (trained community member } \\
\text { supported by government sample analysis), } \\
\text { per previous proposal to CFIA }\end{array}$ \\
\hline $\begin{array}{l}\text { Data and } \\
\text { knowledge } \\
\text { sharing }\end{array}$ & $\begin{array}{l}\text { Information sharing } \\
\text { between health authorities } \\
\text { and First Nations } \\
\text { communities } \\
\text { - For example, essential } \\
\text { harvesting and food } \\
\text { preparation practices }\end{array}$ & $\begin{array}{l}\text { Environmental monitoring data are not } \\
\text { publicly accessible, including by health } \\
\text { authorities and First Nations communities } \\
\text { - Establish collaborative monitoring systems } \\
\text { that encourage open and transparent } \\
\text { information sharing to support risk } \\
\text { assessment and inform harvesting }\end{array}$ \\
\hline Clarified roles & BCCDC-led research & $\begin{array}{l}\text { Regional health authorities were not fully } \\
\text { aware of the potential for additional support } \\
\text { from agencies (laboratory capacity, } \\
\text { investigation, and risk assessment), leading to } \\
\text { potential delays } \\
\text { - Refine communicable disease protocols to } \\
\text { clarify coordination responsibilities and } \\
\text { pathways to ensure that all relevant parties } \\
\text { are engaged at initial stages }\end{array}$ \\
\hline $\begin{array}{l}\text { Appropriate and } \\
\text { meaningful } \\
\text { knowledge for } \\
\text { decision- } \\
\text { making (to all } \\
\text { parties) }\end{array}$ & $\begin{array}{l}\text { Knowledge translation } \\
\text { enhanced by the existing } \\
\text { and active collaboration } \\
\text { between First Nations } \\
\text { communities and FNHA }\end{array}$ & $\begin{array}{l}\text { Knowledge and knowledge translation gaps } \\
\text { were identified } \\
\text { - With the changing environment may come } \\
\text { changes in risk factors that need to be } \\
\text { considered in traditional harvest and } \\
\text { distribution } \\
\text { - Ecological knowledge of climate change } \\
\text { and its impacts to the environment needs to } \\
\text { be improved, and research needs identified } \\
\text { - Public health messaging needs to be } \\
\text { created for future harvests }\end{array}$ \\
\hline
\end{tabular}




\section{Conclusions}

The $V$. cholerae outbreak along the BC coast in 2018 highlighted the importance of bringing together different ways of knowing and the need for continued and further improved collaboration between diverse agencies and Indigenous communities. Local First Nations' knowledge of harvest locations, practices, and conditions was critical to the investigation and risk assessment. Intervention outcomes would also not have been as successful had the community members not supported the practical aspects of investigation with vessel and local navigation support to FNHA staff for the environmental sample collection.

Climate change will increase the frequency of emerging, unforeseen public health emergencies, and it requires new, innovative approaches to collaborative outbreak investigation and management. First Nations and other Indigenous communities are at the forefront of climate change (Downing \& Cuerrier, 2011). They hold considerable holistic traditional and place-based knowledge that is often absent in Western public health and academic discourse and can offer guidance in responding to (or, more importantly, preventing) climate change events that go far beyond just traditional foods. As health and wellness partners with First Nations, public health service providers must co-create a relevant, credible, legitimate evidence base and practical scientific guidance to support healthy traditional food consumption under changing climate conditions.

Our recommendation to relevant stakeholders is to further develop sustainable institutional relationships between partners, including local First Nations communities. It is also critical to ensure that Indigenous communities are involved as equal partners and that protocols support communities' self-determination. This $V$. cholerae outbreak and the existing literature indicate that supportive systems and interventions are most effective when they involve affected Indigenous communities in a respectful and culturally safe manner. We propose that more research should be conducted to help develop Indigenous monitoring programs that enable sufficient parameters for tracking and understanding climate trends, and enabling correlations and risk predictions for both $V$. cholerae and other pathogens. We also suggest that BC public health authorities and marine authorities collaborate to develop a new operational framework to increase trust and reduce fears in future harvests of herring eggs.

\section{References}

Anderson, M. J., \& Smylie, J. K. (2009). Health systems performance measurement systems in Canada: How well do they perform in First Nations, Inuit, and Métis contexts? Pimatisiwin: A Journal of Aboriginal and Indigenous Community Health, 7(1), 99-115. https://www.ncbi.nlm.nih.gov/pmc/articles/PMC3582648/

Ansell, C., \& Gash, A. (2008). Collaborative governance in theory and practice. Journal of Public Administration Research and Theory, 18(4), 543-571. https://doi.org/10.1093/jopart/mum032

Aron, J. L., \& Patz, J. A. (Eds.). (2001). Ecosystem change and public health: A global perspective. Johns Hopkins University Press. 
Auth, T. D., Daly, E. A., Brodeur, R. D., \& Fisher, J. L. (2018). Phenological and distributional shifts in ichthyoplankton associated with recent warming in the northeast Pacific Ocean. Global Change Biology, 24(1), 259-272. https://doi.org/10.1111/gcb.13872

Baba, L. (2013). Cultural safety in First Nations, Inuit and Métis public health: Environmental scan of cultural competency and safety in education, training and health services. National Collaborating Centre for Aboriginal Health. https://www.ccnsanccah.ca/docs/emerging/RPT-CulturalSafetyPublicHealth-Baba-EN.pdf

Baker-Austin, C., Trinanes, J., Gonzalez-Escalona, N., \& Martinez-Urtaza, J. (2017). Noncholera vibrios: The microbial barometer of climate change. Trends in Microbiology, 25(1), P76-84. https://doi.org/10.1016/j.tim.2016.09.008

Berkes, F. (2010). Devolution of environment and resources governance: Trends and future. Environmental Conservation, 37(4), 489-500. https://doi.org/10.1017/S037689291000072X

British Columbia Centre for Disease Control. (2016). Marine biotoxin workshop [Links to proceedings of workshop held October 24-25, 2016, North Vancouver, BC). http://www.bccdc.ca/health-professionals/education-development/marine-biotoxinworkshop

British Columbia Foodborne Illness Outbreak Response Protocol (BC FIORP): Guide to multiagency response in British Columbia. (2012). Retrieved from BC Centre for Disease Control website: https://www.bccdc.ca/resource-gallery/Documents/Guidelines and Forms/BCFIORP2012.pdf

British Columbia Tripartite Framework Agreement on First Nation Health Governance, October 13, 2011. Minister of Health, Canada; Minister of Health, British Columbia; and First Nations Health Society; endorsed by First Nations Health Council. http://www.fnhc.ca/pdf/framework-accord-cadre-eng1.pdf

Browne, A. J., Varcoe, C., Ford-Gilboe, M., Wathen, C. N., \& on behalf of the EQUIP Research Team. (2015). EQUIP Healthcare: An overview of a multi-component intervention to enhance equity-oriented care in primary health care settings. International Journal for Equity in Health, 14(1), Article 152. https://doi.org/10.1186/s12939-015-0271-y

Brubaker, M., Berner, J., Chavan, R., \& Warren, J. (2011). Climate change and health effects in northwest Alaska. Global Health Action, 4(1), Article 8445. https://www.tandfonline.com/doi/pdf/10.3402/gha.v4i0.8445

Butterfoss, F. D., Lachance, L. L., \& Orians, C. E. (2006). Building allies coalitions: Why formation matters. Health Promotion Practice, 7(2 Suppl), 23S-33S. https://doi.org/10.1177/1524839906287062

Cash, D. W., Clark, W. C., Alcock, F., Dickson, N. M., Eckley, N., Guston, D. H., Jäger, J., \& Mitchell, R. B. (2003). Knowledge systems for sustainable development. Proceedings of the National Academy of Sciences, 100(14), 8086-8091. https://doi.org/10.1073/pnas.1231332100

Chino, M., \& DeBruyn, L. (2006). Building true capacity: Indigenous models for Indigenous communities. American Journal of Public Health, 96(4), 596-599. https://doi.org/10.2105/AJPH.2004.053801 
Chrismas, R. (2012). The people are the police: Building trust with Aboriginal communities in contemporary Canadian society. Canadian Public Administration, 55(3), 451-470. https://doi.org/10.1111/j.1754-7121.2012.00231.x

Cisneros-Montemayor, A. M., Pauly, D., Weatherdon, L. V., \& Ota, Y. (2016). A global estimate of seafood consumption by coastal Indigenous Peoples. PLoS ONE, 11(12), Article e0166681. https://doi.org/10.1371/journal.pone.0166681

Constitution Act [Canada], 1867, s. 91(24).

Constitution Act, 1982 [enacted by the Canada Act, 1982 (U.K.), c. 11, s. 1], pt. I (Canadian Charter of Rights and Freedoms), s. 35.

de Leeuw, S., Cameron, E. S., \& Greenwood, M. L. (2012). Participatory and community-based research, Indigenous geographies, and the spaces of friendship: A critical engagement. The Canadian Geographer, 56(2), 180-194. https://doi.org/10.1111/j.15410064.2012.00434.x

Donatuto, J. L., Satterfield, T. A., \& Gregory, R. (2011). Poisoning the body to nourish the soul: Prioritising health risks and impacts in a Native American community. Health, Risk \& Society, 13(2), 103-127. https://doi.org/10.1080/13698575.2011.556186

Downing, A., \& Cuerrier, A. (2011). A synthesis of the impacts of climate change on the First Nations and Inuit of Canada. Indian Journal of Traditional Knowledge, 10(1), 57-70. https://nopr.niscair.res.in/bitstream/123456789/11066/1/IJTK 10(1) 57-70.pdf

Engel, M. F., Muijsken, M. A., Mooi-Kokenberg, E., Kuijper, E. J., \& van Westerloo, D. J. (2016). Vibrio cholerae non-O1 bacteraemia: Description of three cases in the Netherlands and a literature review. Eurosurveillance, 21(15), Article 30197. https://doi.org/10.2807/1560-7917.ES.2016.21.15.30197

First Nations Health Authority. (2016). Cultural safety \& humility. https://www.fnha.ca/wellness/cultural-humility

First Nations Health Council. (2011). Implementing the vision: BC First Nations health governance. https://www.fnha.ca/Documents/FNHC_Health_Governance_Book.pdf

Fogarty, W., Lovell, M., Langenberg, J., \& Heron, M-J. (2018). Deficit discourse and strengthsbased approaches: Changing the narrative of Aboriginal and Torres Strait Islander health and wellbeing, The Lowitja Institute and National Centre for Indigenous Studies, Australia National University. https://ncis.anu.edu.au/_lib/doc/ddih/Deficit_Discourse_and_Strengthsbased_Approaches_FINAL_WEB.pdf

Greenwood, M., Lindsay, N., King, J., \& Loewen, D. (2017). Ethical spaces and places: Indigenous cultural safety in British Columbia health care. AlterNative: An International Journal of Indigenous Peoples, 13(3), 179-189. https://doi.org/10.1177/1177180117714411

Haegele, C. W., \& Schweigert, J. F. (1985). Distribution and characteristics of herring spawning grounds and description of spawning behaviour. Canadian Journal of Fisheries and Aquatic Sciences, 42(S1), s39-s55. https://doi.org/10.1139/f85-261 
Hanson, E. (n.d.) Reserves. Indigenous Foundations, University of British Columbia. https://indigenousfoundations.arts.ubc.ca/reserves/

Harris, D. C., \& Millerd, P. (2010). Food fish, commercial fish, and fish to support a moderate livelihood: Characterizing Aboriginal and treaty rights to Canadian fisheries. Arctic Review on Law and Politics, 1, 82-107. https://papers.ssrn.com/sol3/papers.cfm?abstract_id=1594272

Hopkins, C. R., Bailey, D. M., \& Potts, T. (2016). Perceptions of practitioners: Managing marine protected areas for climate change resilience. Ocean \& Coastal Management, 128, 1828. https://doi.org/10.1016/j.ocecoaman.2016.04.014

Hunter, K. L., \& Wade, J. (Eds.). (2015). Pacific large aquatic basin climate change impacts, vulnerabilities and opportunities assessment-Marine species and aquaculture. Canadian Manuscript Report Fisheries and Aquatic Sciences 3049, Fisheries and Oceans Canada. https://waves-vagues.dfo-mpo.gc.ca/Library/359365.pdf

Karunasagar, I. (2009). Molecular tools for improving seafood safety. In H. W. Doelle, J. F. Rokem, \& M. Berovic (Eds.), Biotechnology: Vol. IX. Fundamentals in biotechnology (pp. 105-119). UNESCO-EOLSS. https://www.eolss.net/Sample-Chapters/C17/E6-5808-04.pdf

Keeling, B., Hessing-Lewis, M., Housty, C., Okamoto, D. K., Gregr, E. J., \& Salomon, A. K. (2017). Factors driving spatial variation in egg survival of an ecologically and culturally important forage fish. Aquatic Conservation: Marine and Freshwater Ecosystems, 27(4), 814-827. https://doi.org/10.1002/aqc.2757

Kurtz, D. L. M., Nyberg, J. C., Van Den Tillaart, S., \& Mills, B. (2008). Silencing of voice: An act of structural violence: Urban Aboriginal women speak out about their experiences with health care. Journal of Aboriginal Health [now International Journal of Indigenous Health], 4(1), 53-63. https://doi.org/10.18357/ijih41200812315

Kwiatkowski, R. E. (2011). Indigenous community based participatory research and health impact assessment: A Canadian example. Environmental Impact Assessment Review, 31(4), 445-450. https://doi.org/10.1016/j.eiar.2010.02.003

Lavoie, J., Gervais, L., Toner, J., Bergeron, O., \& Thomas, G. (2011). The Aboriginal health legislation and policy framework in Canada. National Collaborating Centre for Aboriginal Health. https://www.ccnsa-nccah.ca/docs/context/FSHealthLegislationPolicy-Lavoie-Gervais-Toner-Bergeron-Thomas-EN.pdf

Laycock, A., Bailie, J., Matthews, V., \& Bailie, R. (2019). Using developmental evaluation to support knowledge translation: Reflections from a large-scale quality improvement project in Indigenous primary healthcare. Health Research Policy and Systems, 17(1), Article 70. https://doi.org/10.1186/s12961-019-0474-6

Loppie, S., Reading, C., \& de Leeuw, S. (2014). Aboriginal experiences with racism and its impacts. National Collaborating Centre for Aboriginal Health. https://www.nccahccnsa.ca/Publications/Lists/Publications/Attachments/131/2014_07_09_FS_2426_Racis mPart2_ExperiencesImpacts_EN_Web.pdf 
Lynn, K., Daigle, J., Hoffman, J., Lake, F., Michelle, N., Ranco, D., Viles, C., Voggesser, G., \& Williams, P. (2013). The impacts of climate change on tribal traditional foods. Climatic Change, 120(3), 545-556. https://doi.org/10.1007/s10584-013-0736-1

Mandal, S., Mandal, M. D., \& Pal, N. K. (2011). Cholera: A great global concern. Asian Pacific Journal of Tropical Medicine, 4(7), 573-580. https://doi.org/10.1016/S19957645(11)60149-1

Marinucci, G. D., Luber, G., Uejio, C. K., Saha, S., \& Hess, J. J. (2014). Building resilience against climate effects-A novel framework to facilitate climate readiness in public health agencies. International Journal of Environmental Research and Public Health, 11(6), 6433-6458. https://doi.org/10.3390/ijerph110606433

McClymont Peace, D., \& Myers, E. (2012). Community-based participatory process - Climate change and health adaptation program for northern First Nations and Inuit in Canada. International Journal of Circumpolar Health, 71(1), Article 18412. https://doi.org/10.3402/ijch.v71i0.18412

Minkler, M., \& Wallerstein, N. (2012). Improving health through community organization and community building: Perspectives from health education and social work. In M. Minkler (Ed.), Community organizing and community building for health and welfare (3rd ed., pp. 37-58). Rutgers University Press. https://doi.org/10.36019/9780813553146-005

Moore, S. K., Trainer, V. L., Mantua, N. J., Parker, M. S., Laws, E. A., Backer, L. C., \& Fleming, L. E. (2008). Impacts of climate variability and future climate change on harmful algal blooms and human health. Environmental Health, 7(Suppl. 2), Article S4. https://doi.org/10.1186/1476-069X-7-S2-S4

Moss, M. L. (2016). The nutritional value of Pacific herring: An ancient cultural keystone species on the Northwest Coast of North America. Journal of Archaeological Science: Reports, 5, 649-655. https://doi.org/10.1016/j.jasrep.2015.08.041

Narine, S. (2013). Racism, mistrust keep Aboriginal people from health care. Windspeaker, 30(11). http://www.ammsa.com/publications/windspeaker/racism-mistrust-keepaboriginal-people-health-care

National Health and Welfare \& Treasury Board of Canada. (1989). Memorandum of understanding between the Minister of National Health and Welfare and the Treasury Board concerning the transfer of health services to Indian control. Ottawa, ON: Government of Canada.

O’Neil, J., Gallagher, J., Wylie, L., Bingham, B., Lavoie, J., Alcock, D., \& Johnson, H. (2016). Transforming First Nations' health governance in British Columbia. International Journal of Health Governance, 21(4), 229-244. https://doi.org/10.1108/IJHG-08-20160042

Panic, M., \& Ford, J. D. (2013). A review of national-level adaptation planning with regards to the risks posed by climate change on infectious diseases in 14 OECD nations. International Journal of Environmental Research and Public Health, 10(12), 7083-7109. https://doi.org/10.3390/ijerph10127083

Patton, M. Q. (2002). Qualitative research and evaluation methods (3rd ed.). Sage Publications. 
Patton, M. Q. (2011). Developmental evaluation: Applying complexity concepts to enhance innovation and use. Guilford Press.

Public Health Act [British Columbia], SBC 2008, c. 28. https://www.bclaws.ca/civix/document/id/complete/statreg/08028_01

Putnam, R. D. (1994). Making democracy work: Civic traditions in modern Italy. Princeton University Press. https://doi.org/10.1515/9781400820740

Putnam, R. D. (2000). Bowling alone: The collapse and revival of American community. Simon \& Schuster.

R. v. Quipp, BCCA 235 (2011). https://www.canlii.org/en/bc/bcca/doc/2011/2011bcca235/2011bcca235.html

Raymond, C. M., Fazey, I., Reed, M. S., Stringer, L. C., Robinson, G. M., \& Evely, A. C. (2010). Integrating local and scientific knowledge for environmental management. Journal of Environmental Management, 91(8), 1766-1777. https://doi.org/10.1016/j.jenvman.2010.03.023

Rodriguez-Mozaz, S., \& Weinberg, H. S. (2010). Meeting report: Pharmaceuticals in water-An interdisciplinary approach to a public health challenge. Environmental Health Perspectives, 118(7), 1016-1020. https://doi.org/10.1289/ehp.0901532

Shrivastava, R., Couturier, Y., Simard-Lebel, S., Girard, F., Aguirre, N. V. B., Torrie, J., \& Emami, E. (2019). Relational continuity of oral health care in Indigenous communities: A qualitative study. BMC Oral Health, 19(1), Article 287. https://doi.org/10.1186/s12903019-0986-Z

Spence, N. (2017). The changing landscape of health emergency management. Queens Policy Review, 8(1), 72-85.

https://www.queensu.ca/sps/qpr/sites/webpublish.queensu.ca.qprwww/files/files/2017/07 $\% 20-\% 20$ Nicole $\% 20$ Spence $\% 20$ -

$\% 20$ The $\% 20$ Changing\%20Landscape $\% 20$ of\%20Health\%20Emergency\%20Management .docx.pdf

Stephen, C., \& Duncan, C. (2017). Can wildlife surveillance contribute to public health preparedness for climate change? A Canadian perspective. Climatic Change, 141(2), 259-271. https://doi.org/10.1007/s10584-016-1892-X

Thornton, T. F., Moss, M. L., Butler, V. L., Hebert, J., \& Funk, F. (2010). Local and traditional knowledge and the historical ecology of Pacific herring in Alaska. Journal of Ecological Anthropology, 14(1), 81-88. https://doi.org/10.5038/2162-4593.14.1.7

Tirado, M. C., Clarke, R., Jaykus, L. A., McQuatters-Gollop, A., \& Frank, J. M. (2010). Climate change and food safety: A review. Food Research International, 43(7), 1745-1765. https://doi.org/10.1016/j.foodres.2010.07.003

Truesdale, C., \& Brooks, K. (2017). A guide to Aboriginal harvesting rights: Fishing, hunting, trapping, gathering. Legal Services Society. https://legalaid.bc.ca/publications/pub/guide-aboriginal-harvesting-rights 
Turner, N. J., \& Clifton, H. (2009). "It's so different today": Climate change and Indigenous lifeways in British Columbia, Canada. Global Environmental Change, 19(2), 180-190. https://doi.org/10.1016/j.gloenvcha.2009.01.005

U.S. Climate Resilience Toolkit. (2020). Alaskan tribes join together to assess harmful algal blooms. https://toolkit.climate.gov/case-studies/alaskan-tribes-join-together-assessharmful-algal-blooms

Vezzulli, L., Colwell, R. R., \& Pruzzo, C. (2013). Ocean warming and spread of pathogenic vibrios in the aquatic environment. Microbial Ecology, 65(4), 817-825. https://doi.org/10.1007/s00248-012-0163-2

Wine, O., Ambrose, S., Campbell, S., Villeneuve, P. J., Kovacs Burns, K., \& Vargas, A. O. (2017). Key components of collaborative research in the context of environmental health: A scoping review. Journal of Research Practice, 13(2), Article R2. http://jrp.icaap.org/index.php/jrp/article/view/577/477

Xu, Y., Fu, C., Peña, A., Hourston, R., Thomson, R., Robinson, C., Cleary, J., Daniel, K., \& Thompson, M. (2019). Variability of Pacific herring (Clupea pallasii) spawn abundance under climate change off the west coast of Canada over the past six decades. Journal of Marine Systems, 200, Article 103229. https://doi.org/10.1016/j.jmarsys.2019.103229 


\section{Appendix}

Food Handling Recommendations Provided by Health Canada

\begin{tabular}{|c|c|c|}
\hline Before Harvest & During Harvest & After Harvest \\
\hline $\begin{array}{l}\text { Sanitize totes, } \\
\text { equipment, } \\
\text { and any } \\
\text { seafood } \\
\text { contact } \\
\text { surfaces }\end{array}$ & $\begin{array}{l}\text { - Wash hands } \\
\text { - Rinse eggs with } \\
\text { potable water or } \\
\text { use boiled and } \\
\text { cooled saltwater } \\
\text { - Temperature } \\
\text { control }\end{array}$ & $\begin{array}{l}\text { - Wash hands } \\
\text { - } \text { Temperature control during transportation } \\
\text { - Sanitize equipment and utensils } \\
\text { - Cook to internal temperature of } 63{ }^{\circ} \mathrm{C} \text { for } 15 \\
\text { seconds to destroy bacteria. Blanch to reduce } \\
\text { bacterial levels. } \\
\text { - If cooking is not preferred, be aware that there } \\
\text { is always risk with eating raw seafood } \\
\text { - Under refrigeration storage at } 4{ }^{\circ} \mathrm{C} \text { or lower, } \\
\text { shelf life of } 1-2 \text { days }\end{array}$ \\
\hline
\end{tabular}

Note. Instructions specific to this event provided to FNHA as guidance by Health Canada. 